Dwidienawati, D. (septiembre-diciembre, 2021). Revisit the implementation of E-Learning: Lesson Learned from COVID-19 pandemic. Revista Virtual Universidad Católica del Norte, (64), 1-4. https://www.doi.org/10.35575/rvucn.n64a1

\title{
Revisit the implementation of E-Learning: Lesson Learned from COVID-19 pandemic
}

\section{Revisar la implementación del aprendizaje electrónico: lección aprendida de la pandemia}

\section{COVID-19}

\author{
Diena Dwidienawati \\ Doctor Research in Management (DRM) \\ Bina Nusantara University \\ Jakarta, Indonesia \\ diena.tjiptadi@gmail.com \\ Orcid: https://orcid.org/0000-0003-0072-9689
}

The COVID-19 outbreak does not only have an impact on human health, but it also impacts other aspects of human life, including the education sector (Huang et al., 2020). In many countries, health authorities' recommendation forced the education sector to find an alternative to face-toface delivery methods. The e-learning implementation during the COVID-19 outbreak is crucial. Because of how long the COVID-19 outbreak will last, nobody can confirm that the learning process should be undisrupted in the case of disruption.

E-learning is defined as "learning experiences in synchronous or asynchronous environments using different devices (e.g., mobile phones, laptops, etc.) with internet access" (Huang et al., 2020). E-learning is an internet-enabled teaching method. It is considered as a new innovative approach in delivering education (Huang et al., 2020; Pham et al., 2018). E-learning gives students options of time, place and pace in pursuing their education.

Before the COVID-19 outbreak, e-learning has been quite popular. Many universities had moved their focus survey in the US in 2015 showed that the number of students taking online classes is increasing from $3,7 \%$ to $3.9 \%$. One in four students takes at least one online course in 
one year. Sixty per cent of academic leaders consider that e-learning will be essential for long term growth (Chakravorti \& Chaturvedi, 2019). Experts have predicted that the 'residential based model" of learning will disappear in the near future (Shachar \& Neumann, 2010). There are many indications that e-learning will keep increasing as many other internet advanced applications are used in the process (Pham et al., 2018).

However, one primary concern is the effectiveness of e-learning. Previous studies proved that e-learning is effective. There are no significant differences in course scores, student engagement, and student satisfaction between online and offline learning methods (Manion, 2019). This claim is proven by the majority of academic research (Chakravorti \& Chaturvedi, 2019). However, most of the studies of e-learning were targeted students who had the intention to pursue their education online. During COVID-19, students are forced to have e-learning. Are there any concerns about e-learning effectiveness?

The author has conducted several studies on e-learning and people wellbeing during the COVID-19 outbreak. One study on e-learning showed that the critical factors that influence elearning satisfaction are the quality of service, how useful and easy the system used in e-learning perceived by students (Dwidienawati, Abdinagoro, Tjahjana, Gandasari et al., 2020). During the beginning of e-learning implementation, the student satisfaction rate is only slightly satisfied. Students like e-learning include flexibility, accessibility, less time consuming, and more relax (Dwidienawati, Bramatoro et al., 2020). However, e-learning has some drawback such as lack of interaction, feeling isolated and highly dependent on internet connection. A study from similar authors revealed that around 33\% of students and lecturers were unsatisfied with their performance from e-learning (Dwidienawati, Abdinagoro, Tjahjana \& Gandasari, 2020). Approximately 63\% of students found it challenging to follow e-learning program (Gandasari \& Dwidienawati, 2020). As a result, more than $80 \%$ of students prefer face-to-face learning to e-learning (Dwidienawati, Bramatoro et al., 2020).

Before COVID-19, e-learning seemed like a new innovative approach to replace face-to-face learning. However, the recent studies from during the COVID-19 outbreak, the full shift learning approach to e-learning showed major drawbacks of the $100 \%$ implementation. It is highly dependable to the internet is one issue. Even in the big cities, the internet connection is still not 
stable, which will lead to disturbing the learning process. Second, e-learning has offered a lack of interaction and connection among students and lecturers. As a social creature, the human being needs to have a connection with others. The internet-based connection, such as Zoom and Google meet, cannot replace the need for 'feel and touch'. With e-learning, students and lecturers cannot build a close relationship. With e-learning, some soft skills such as public speaking, presentation skill, reading non-verbal cue are not learned. Third, both lecturers and students are not sure about the effectiveness of e-learning.

\section{References}

Chakravorti, B., \& Chaturvedi, R. S. (2019). Ranking 42 Countries by Ease of Doing Digital Business. Harvard Business Review Home. https://hbr.org/2019/09/ranking-42-countriesby-ease-of-doing-digital-business

Dwidienawati, D., Abdinagoro, S. B., Tjahjana, D., Gandasari, D., \& Munawaroh, Z. (2020). Forced shifting to e-learning during the covid-19 outbreak: Information quality, system quality, service quality, and goal orientation influence to e-learning satisfaction and perceived performance. International Journal of Advanced Trends in Computer Science and $\quad$ Engineering, $\quad$ 1518-1525. http://www.warse.org/IJATCSE/static/pdf/file/ijatcse93922020.pdf

Dwidienawati, D., Abdinagoro, S. B., Tjahjana, D., \& Gandasari, D. (2020). E-Learning Implementation during The COVID-19 outbreak: The Perspective of Students and Lecturers. Jourlan of the Social Sciences, 48(4), 1190-1201.

Dwidienawati, D., Bramatoro, S., \& Tjahjana D. (2020). Face-to-Face and Lessons Learned from the Forced Shift to E-Learning during the COVID-19 Outbreak. International Journal of Innovation, Creativity and Change, 13(11), 119-134.

Gandasari, D., \& Dwidienawati, D. (2020). Evaluation of Online Learning with Digital Communication media during the COVID 19 Pandemic. Jourlan of the Social Sciences, 48(3), 1062-1073. $\quad$ https://www.researchgate.net/profile/DGandasari/publication/343569066_1062- 


\section{0/links/5f321312299bf13404b72342/1062-107321470.pdf}

Huang, R. H., Liu, D. J., Tlili, A., Yang, J. F., Wang, H.H., et al. (2020). Handbook on Facilitating Flexible Learning During Educational Disruption: The Chinese Experience in Maintaining Undisrupted Learning in COVID-19 Outbreak. Smart Learning Institute of Beijing Normal University. $\underline{\text { https://iite.unesco.org/wp- }}$ content/uploads/2020/03/Handbook-on-Facilitating-Flexible-Learning-in-COVID-19Outbreak-SLIBNU-V1.2-20200315.pdf

Manion, J. L. (2019). A Mixed Methods Investigation of Student Achievement and Satisfaction in Traditional versus Online Learning Environments (Doctoral dissertation). Lindenwood University.

https://search.proquest.com/openview/2a0d1b80a23dc5e25d9fbf86aa71c2f4/1?pqorigsite $=$ gscholar $\& \mathrm{cbl}=18750 \&$ diss $=\mathrm{y}$

Pham, L., Williamson, S., \& Berry R. (2018). Student perceptions of E-learning service quality, E-satisfaction, and E-loyalty. International Journal of Enterprise Information, 14(3):19-40. https://doi.org/10.4018/IJEIS.2018070102

Shachar, M., \& Neumann, Y. (2010). Twenty years of research on the academic performance differences between traditional and distance learning: Summative meta-analysis and trend. MERLOT Journal of Online Learning and Teaching, 6(2), 318-334. http://jolt.merlot.org/vol6no2/shachar_0610.pdf 